\title{
Characterization of ligno-cellulosic materials bleached with oxo-diperoxo-molybdates
}

\author{
Cecilia Sîrghie a , Adina-Maria Bodescu ${ }^{\mathrm{b}}$, Alexandru Botar $^{\mathrm{a}}$, Artur Cavaco-Paulo $^{\mathrm{c}}$, \\ Florentina-Daniela Munteanu ${ }^{\mathrm{b}, *}$ \\ a Research Development Innovation in Natural and Technical Sciences Institute of “Aurel Vlaicu” University of Arad, Elena Drăgoi 2, Arad 310330, Romania \\ b "Aurel Vlaicu" University of Arad, Faculty of Food Engineering, Tourism and Environmental Protection, Elena Drăgoi 2, Arad 310330, Romania \\ ' IBB-Institute for Biotechnology and Bioengineering, Centre of Biological Engineering, University of Minho, Campus de Gualtar, 4710-057, Braga, Portugal
}

\section{A R T I C L E I N F O}

\section{Article history:}

Received 8 January 2013

Received in revised form 26 May 2013

Accepted 18 June 2013

Available online 26 June 2013

\section{Keywords:}

Linen-cotton fabric

Oxo-diperoxo molybdates

Cyclic voltammetry

Whiteness index

Thermal analysis

FT-IR analysis

\begin{abstract}
A B S T R A C T
A newly effective system was used to bleach ligno-cellulosic textile materials. This system is based on two different newly synthesized natrium oxo-diperoxo molybdates, $\mathrm{Na}_{2}\left[\mathrm{MoO}\left(\mathrm{O}_{2}\right)_{2}\left(\mathrm{C}_{2} \mathrm{O}_{4}\right)\right]$ and $\mathrm{Na}_{2}[\mathrm{MoO}$ $\left.\left(\mathrm{O}_{2}\right)_{2}\left(\mathrm{C}_{6} \mathrm{H}_{6} \mathrm{O}_{7}\right)\right]$.

These two compounds were characterized by means of cyclic voltammetry, and the bleached fabrics were fully characterized by measuring their whiteness index, percent loss in fabric weight and the content of lignin in the fabric. The obtained results revealed that good whiteness index of the bleached linencotton fabrics ( $50 \%$ linen and $50 \%$ cotton) and low content of lignin could be obtained by soaking the fabric for $55 \mathrm{~min}$ at $90{ }^{\circ} \mathrm{C}$ in a solution containing $3.5 \%$ of molybdate complex and $3.5 \% \mathrm{H}_{2} \mathrm{O}_{2}$.
\end{abstract}

(c) 2013 Elsevier Ltd. All rights reserved.

\section{Introduction}

Beside cellulose, flax fibres have in their structure a high content of pectin and lignin. Lignin is a constituent which has a high molecular mass (over 10,000 amu), is hydrophobic and is responsible for the colour of the raw flax fibres.

Bleaching refers to the removal of the unwanted dark colour and photo-yellowing that are given by the residual lignin present in the fibres (Abdel-Halim \& Al-Deyab, 2011, 2012; Abdel-Halim, 2012a, b; Basto, Tzanov \& Cavaco-Paulo, 2007; Dence \& Reeve, 1996; El Shafie, Fouda, \& Hashem, 2009; Hiseh, Thompson \& Miller, 1996; Mistik \& Yükseloğlu, 2005).

The role of bleaching is to achieve the desired brightness of the ligno-cellulosic textile materials. This process should be selective in respect to the lignin oxidation by means of mechanical properties of the bleached material.

Beside its importance, bleaching is also one of the most expensive processes. The high costs are due to the high amount of chemicals used in the final bleaching stages. Usually, the bleaching process comprises of three steps: soaking of the fabric in bleaching

\footnotetext{
* Corresponding author. Tel.: +40 257283 010; fax: +40 257280070

E-mail address: florentina.munteanu@uav.ro (F.-D. Munteanu).
}

agent and other additive solution; temperature raising; thorough washing and drying the fabric (Vigo, 1994).

Nowadays, because of the negative impact on the environment of the chlorine based bleaching agents, polyoxometalates (POMs) were used as bleaching agents (Evtuguin, Daniel, Silvestre, Amado \& Pascoal Neto, 2000; Weinstock et al., 1997). The main advantage of the polyoxometalates is that these are regenerative oxidizing agents which can easily replace the undesirable chlorine based reagents.

The main objective of the present work was to study the possibility of bleaching linen-cotton fabrics (50\% linen:50\% cotton) by use of two newly synthesized natrium oxodiperoxo molybdates (Bodescu, Sîrghie \& Chambrée, 2011; Bodescu, Vlase, Sîrghie \& Doca, 2012; Sîrghie, Botar, Bodescu \& Dochia, 2012).

This study is the first reported attempt to use oxodiperoxo-molybdates for bleaching the ligno-cellulosic textile materials.

The main contribution of the present study resides in the following aspects: oxo-diperoxo molybdates are easier to be synthesized and are cheaper than polyoxometalates; oxo-diperoxo molybdates are used as bleaching agents in the same concentration range as the polyoxometalates; the whiteness index obtained using the newly synthesized molybdates is achieved with minor or no carbohydrate degradation. 


\section{Experimental}

\subsection{Materials and methods}

Oxalic acid dihydrate, natrium molybdate dihydrate, hydrogen peroxide, ethanol, and citric acid monohydrate were purchased from Merck. Two samples of fabric with the same fibrous composition (50\% linen and $50 \%$ cotton fibres) were used for the bleaching experiments. The total surface of the fabric was $100 \mathrm{~cm}^{2}$. The fabric, named "ELINA article", was manufactured by S.C. FI-RI VIGONIA S.A., Timisoara, Romania.

\subsection{Synthesis of $\mathrm{Na}_{2}\left[\mathrm{MoO}\left(\mathrm{O}_{2}\right)_{2}\left(\mathrm{C}_{2} \mathrm{O}_{4}\right)\right]$ - natrium} oxalate-oxo-diperoxo molybdate

$\mathrm{Na}_{2}\left[\mathrm{MoO}\left(\mathrm{O}_{2}\right)_{2}\left(\mathrm{C}_{2} \mathrm{O}_{4}\right)\right]$ was prepared by the adjustment of the method reported by Bayot, Tinant and Devillers (2004). $1.3 \mathrm{~g}$ of oxalic acid monohydrate was added to $20 \mathrm{~mL}$ solution of sodium molybdate dihydrate, $10 \%$. The solution was stirred for $1 \mathrm{~h}$, thereafter $10 \mathrm{~mL}$ of $\mathrm{H}_{2} \mathrm{O}_{2} 30 \%$ were added. The resulting yellow solution was treated with cold ethanol for complete precipitation of the natrium oxalato-oxo-diperoxo molybdate. After filtration, the compound was carefully washed with cold ethanol and dried at room temperature.

\subsection{Synthesis of $\mathrm{Na}_{2}\left[\mathrm{MoO}\left(\mathrm{O}_{2}\right)_{2}\left(\mathrm{C}_{6} \mathrm{H}_{6} \mathrm{O}_{7}\right)\right]$ - natrium citrate oxo-diperoxo molybdate}

For the preparation of the natrium citrate oxo-diperoxo molybdate the method reported by Dengel, Griffith, Powell and Skapski (1987) was adapted.

$5 \mathrm{~g}$ of sodium molybdate dihydrate were dissolved in $75 \mathrm{~mL}$ of water in the presence of $4.5 \mathrm{~g}$ citric acid. The process was done under continuous stirring.

The newly obtained solution was cooled down to $5^{\circ} \mathrm{C}$, thereafter was added $75 \mathrm{~mL}$ of $\mathrm{H}_{2} \mathrm{O}_{2}$ solution $30 \%$. The resulting solution is yellow. Precipitation of the natrium citrate oxo-diperoxo molybdate is attained by the addition of cold ethanol. After filtration and thorough washing of the solid with ethanol, the drying process was allowed to proceed at room temperature.

\subsection{Electrochemical measurements}

A Voltalab 30 Potentiostat (Radiometer Analytical, France) controlled by the VoltaMaster 4 (version 7.09) electrochemical software was used to perform the electrochemical experiments.

The working, counter, and reference electrodes were: glassy carbon electrode $\left(0.07 \mathrm{~cm}^{2}\right)$, coiled platinum wire $(23 \mathrm{~cm})$, and an $\mathrm{Ag} \mid \mathrm{AgCl}$ electrode filled with $3 \mathrm{M} \mathrm{NaCl}$ (BAS, Bioanalytical Systems, West Lafayette, IN, USA). Prior to the experiments, the surface of the glassy carbon electrode was successively polished with: 5, 1 , 0.3 , and $0.05 \mu \mathrm{m}$ alumina polish (Buehler Ltd, USA). Thereafter, the newly polished electrode was rinsed with $8 \mathrm{M}$ nitric acid and distilled water before use.

The supporting electrolyte used in the electrochemical cell was a solution of $0.1 \mathrm{M}$ citrate or oxalate buffer, $\mathrm{pH}$ 4.0.

All solutions were deoxygenated through bubbling nitrogen for 20 min before measurements.

\subsection{Bleaching of fabric}

Fabric samples (ELINA article) of the same size and weight were treated in a thermostated water bath (Haake) as it follows: firstly, the samples were treated with $0.1 \mathrm{M}$ acetate buffer $\mathrm{pH} 4.5, \mathrm{NaOH}$ $1.2 \%$ and $\mathrm{Na}_{2} \mathrm{SiO}_{3} 5 \%$ at $25^{\circ} \mathrm{C}$. Thereafter, the temperature was raised to $90{ }^{\circ} \mathrm{C}$, and a $3.5 \%$ solution of oxo-diperoxo molybdate and hydrogen peroxide (1:1) was added to the treatment bath, and the process was allowed to proceed for $55 \mathrm{~min}$.

After the bleaching treatment, the samples were washed, dried and weighed.

\subsection{Whiteness of the ligno-cellulosic}

The whiteness index (Berger) $\left(W^{*}\right)$ of the fabrics was determined using a Perkin Elmer Lambda 950 UV/VIS/NIR spectrophotometer, equipped with UV WinLab 6.0 software.

\subsection{Thermal analysis}

The thermogravimetric experiments were performed on a Netzsch STA 409 Luxx system, in a temperature range of $35-600^{\circ} \mathrm{C}$, using alumina crucibles.

The measurements were carried out in air flow $\left(100 \mathrm{~mL} \mathrm{~min}^{-1}\right)$ at $\beta=10 \mathrm{~K} \mathrm{~min}^{-1}$ heating rate. The sample's mass was $\sim 13 \mathrm{mg}$. The TG/DTG/DTA recorded curves were analyzed using the Netzsch Proteus - Thermal Analysis software.

\subsection{FT-IR analysis}

The FT-IR spectra of the initial and isolated complex were recorded at $230^{\circ} \mathrm{C}$ and $430^{\circ} \mathrm{C}$ - in the air atmosphere, respectively at $230^{\circ} \mathrm{C}$ and $383^{\circ} \mathrm{C}$ - in the nitrogen atmosphere. The data were acquired using the Bruker Vertex 70 spectrophotometer, equipped with an ATR cell (Attenuated Total Reflectance). The curves were registered on the $500-4000 \mathrm{~cm}^{-1}$ wavelength range.

The FT-IR spectra of evolved gaseous compounds were obtained on a Perkin-Elmer Spectrum 100-FT-IR spectrometer using UATR technique (EGA).

\section{Results and discussion}

\subsection{Cyclic voltammetry}

These experiments were done at a scan rate of $20 \mathrm{mV} / \mathrm{s}$, and the registered data of the second scan are shown in Figs. 1 and 2.

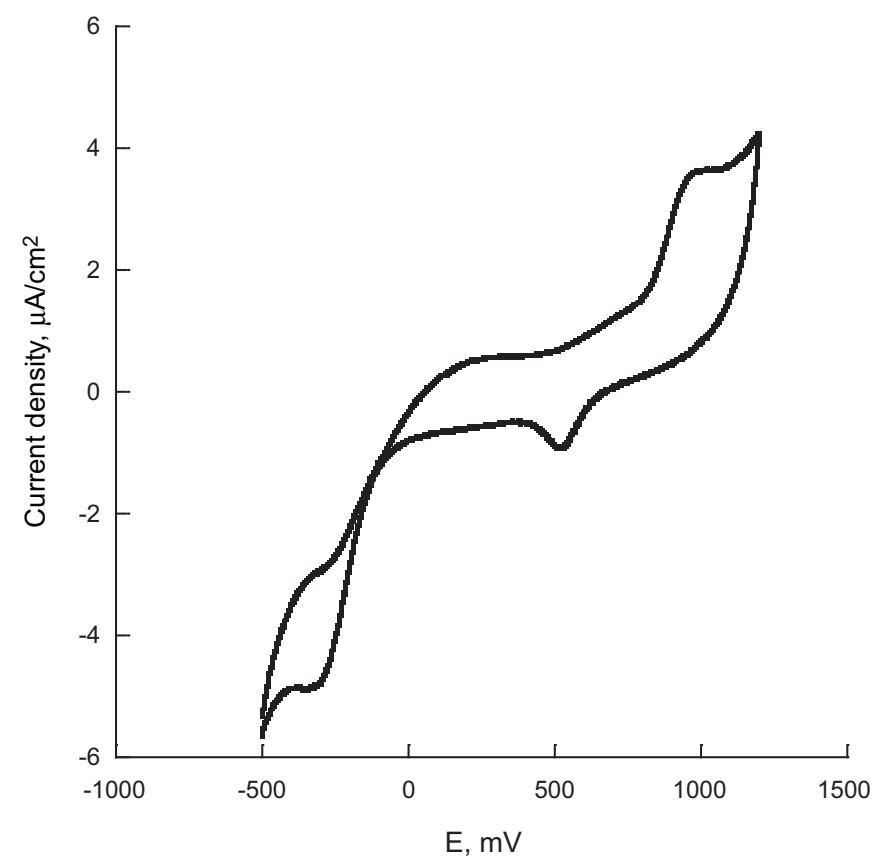

Fig. 1. Cyclic voltammogram of natrium oxalate-oxo-diperoxo molybdate. Scan rate $20 \mathrm{mV} / \mathrm{s}, 0.1 \mathrm{M}$ oxalate buffer, $\mathrm{pH} 4$. 


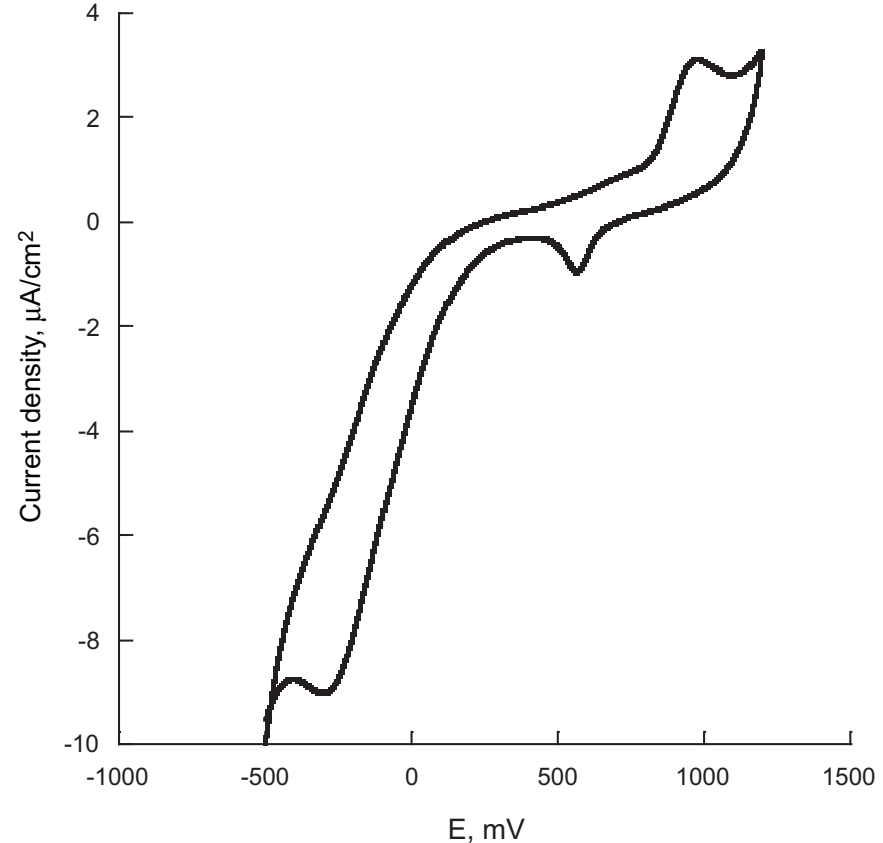

Fig. 2. Cyclic voltammogram of natrium citrate-oxo-diperoxo molybdate. Scan rate $20 \mathrm{mV} / \mathrm{s}, 0.1 \mathrm{M}$ citrate buffer, $\mathrm{pH} 4$.

The influence of the buffer constituents on the registered peak potentials was avoided performing the experiments in the presence of oxalate buffer when natrium oxalate-oxo-diperoxo molybdate was investigated. The study of the natrium citrate-oxo-diperoxo molybdate was done in the presence of citrate buffer. The cyclic voltammograms (Figs. 1 and 2) does not majorly differ for these two newly prepared compounds. Moreover, the dependence of oxidation peak currents on the square root of the scan rate allows us to conclude that the ligand does not influence the behaviour of the studied compounds (Figs. 3 and 4).

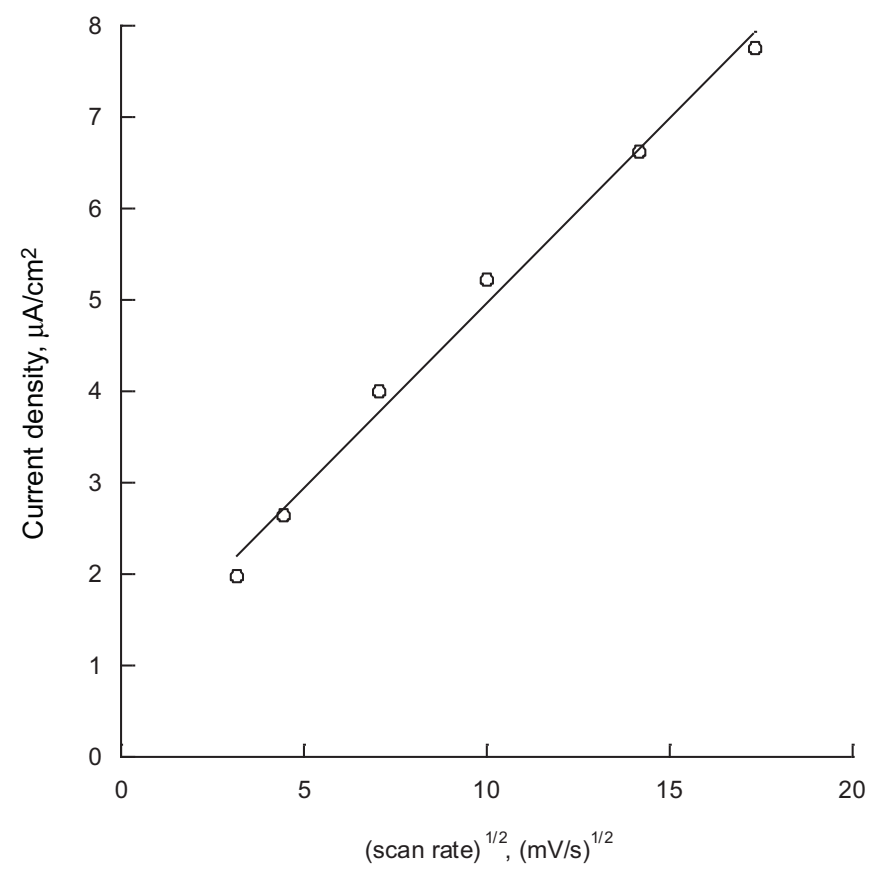

Fig. 3. Dependence of the oxidation peak current of natrium oxalate-oxo-diperoxo molybdate on the square root of the scan rate, registred in $0.1 \mathrm{M}$ oxalate buffer, $\mathrm{pH} 4$.

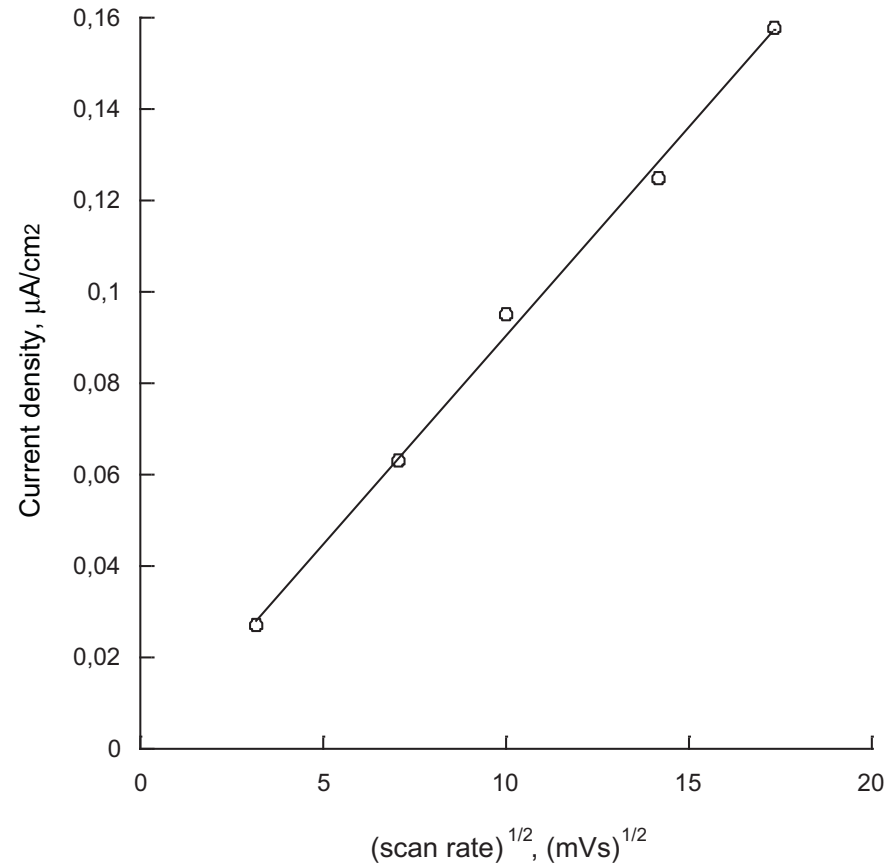

Fig. 4. Dependence of the oxidation peak current of natrium citrate-oxo-diperoxo molybdate on the square root of the scan rate, registred in $0.1 \mathrm{M}$ citrate buffer, $\mathrm{pH} 4$.

\subsection{Bleaching of the ligno-cellulosic textile material using the oxo-diperoxo molybdate (VI) complexes}

\subsubsection{Whiteness index}

The reflectance for the bleached samples was registered at $472 \mathrm{~nm}$. The calculations of the reflectance $(R)$, sorption coefficient $(K)$, and the scattering coefficient $(S)$ were made based on the Kubelka-Munk equation (Kubelka \& Munk, 1931). Based on the values presented in Table 1 , it can be concluded that the samples treated with $\mathrm{Na}_{2}\left[\mathrm{MoO}\left(\mathrm{O}_{2}\right)_{2}\left(\mathrm{C}_{2} \mathrm{O}_{4}\right)\right]$ are whiter than the samples treated with the other complex.

Earlier findings published by Moholkar and Warmoeskerken (2004), show that for a $100 \%$ cotton sample was measured a value of $K / S$ of 0.064 and a corresponding reflectance of $70 \%$. Therefore, it can be concluded that the newly synthesized oxo-diperoxo molybdates can be successfully used for the bleaching of ligno-cellulosic textile materials that are a mixture of linen and cotton ( $50 \%$ cotton and $50 \%$ linen).

The whiteness index (Berger) measured for the fabric bleached with $\mathrm{Na}_{2}\left[\mathrm{MoO}\left(\mathrm{O}_{2}\right)_{2}\left(\mathrm{C}_{2} \mathrm{O}_{4}\right)\right]$ is 51.38 while this value for the fabric bleached with $\mathrm{Na}_{2}\left[\mathrm{MoO}\left(\mathrm{O}_{2}\right)_{2}\left(\mathrm{C}_{6} \mathrm{H}_{6} \mathrm{O}_{7}\right)\right]$ is 47.39 .

These values are comparable with the previous results published by Mistik and Yükseloğlu (2005) a similar treatment scheme of the cotton fabrics in the presence of the ultrasound, but in the absence of molybdates.

It has to be stressed out that, in the present study the fabric samples have a content of $50 \%$ linen and $50 \%$ cotton. For this reason, the fabric used in the present study is less white than the samples used by Mistik et al.

Table 1

Kubelka-Munk values for the samples treated with $\mathrm{Na}_{2}\left[\mathrm{MoO}\left(\mathrm{O}_{2}\right)_{2}\left(\mathrm{C}_{2} \mathrm{O}_{4}\right)\right]$ and $\mathrm{Na}_{2}\left[\mathrm{MoO}\left(\mathrm{O}_{2}\right)_{2}\left(\mathrm{C}_{6} \mathrm{H}_{6} \mathrm{O}_{7}\right)\right]$.

\begin{tabular}{lll}
\hline Sample treated with & $R(\%)$ & $K / S$ \\
\hline $\mathrm{Na}_{2}\left[\mathrm{MoO}\left(\mathrm{O}_{2}\right)_{2}\left(\mathrm{C}_{2} \mathrm{O}_{4}\right)\right]$ & 68.79 & 0.071 \\
$\mathrm{Na}_{2}\left[\mathrm{MoO}\left(\mathrm{O}_{2}\right)_{2}\left(\mathrm{C}_{6} \mathrm{H}_{6} \mathrm{O}_{7}\right)\right]$ & 66.38 & 0.085 \\
\hline
\end{tabular}


(a)

TG $/ \%$

DTG $/(\% / \mathrm{min})$

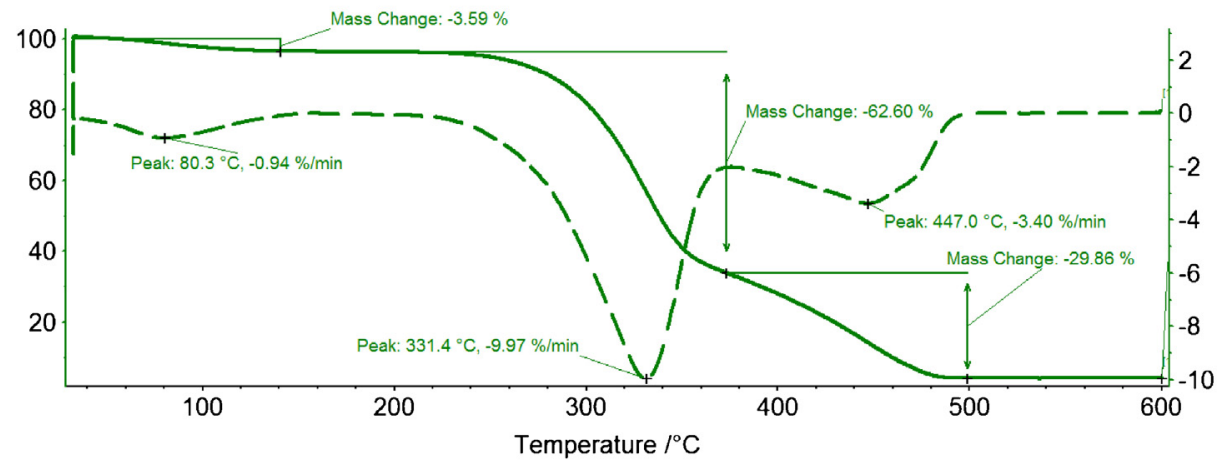

(b)

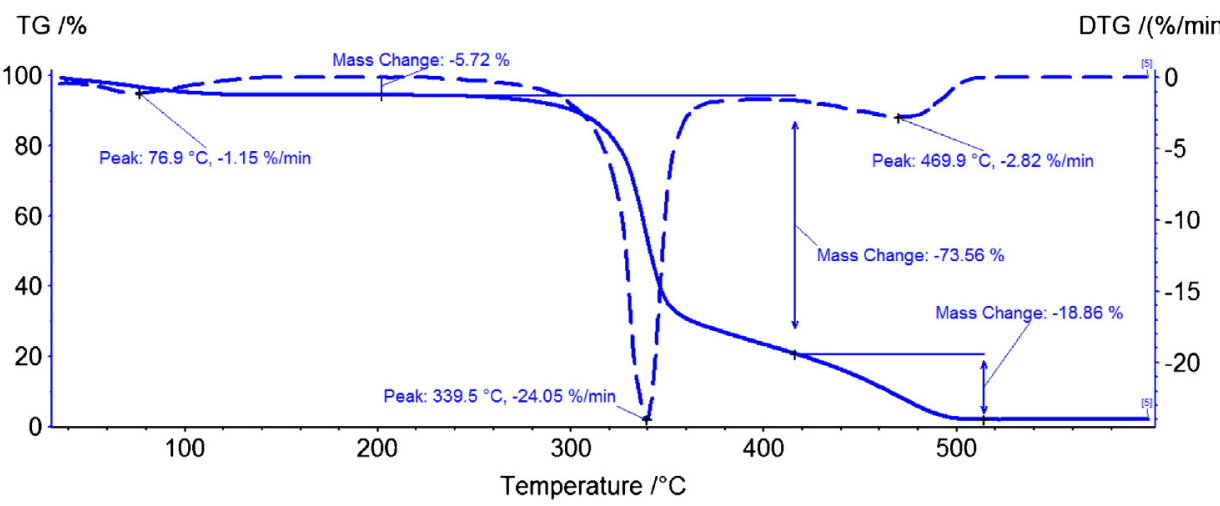

(c)

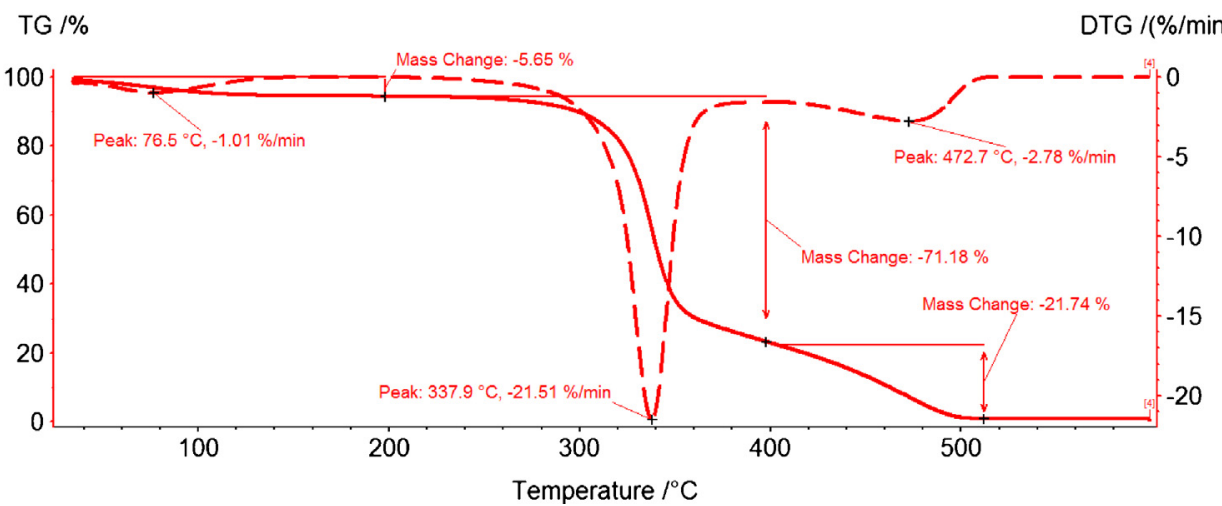

Fig. 5. - TG/DTG curves for: (a) the reference ligno-cellulosic fabric sample. $m_{\text {sample }}=16.8 \mathrm{mg}, \beta=10 \mathrm{~K} \mathrm{~min}^{-1}$; (b) - TG/DTG curves for the reference ligno-cellulosic fabric sample treated with $\mathrm{Na}_{2}\left[\mathrm{MoO}\left(\mathrm{O}_{2}\right)_{2}\left(\mathrm{C}_{2} \mathrm{O}_{4}\right)\right], m_{\text {sample }}=15 \mathrm{mg}, \beta=10 \mathrm{~K} \mathrm{~min}^{-1}$; (c) TG/DTG curves for the reference ligno-cellulosic fabric sample treated with $\mathrm{Na}_{2}\left[\mathrm{MoO}\left(\mathrm{O}_{2}\right)_{2}\left(\mathrm{C}_{6} \mathrm{H}_{6} \mathrm{O}_{7}\right)\right]$, $m_{\text {sample }}=15 \mathrm{mg}, \beta=10 \mathrm{~K} \mathrm{~min}^{-1}$. Continuous line $-\mathrm{TG}$, dashed line $-\mathrm{DTG}$.

Table 2

Mean values of the weight loss recorded in the second and third stages.

\begin{tabular}{|c|c|c|c|}
\hline Thermal analysis & Reference sample & Sample treated with $\mathrm{Na}_{2}\left[\mathrm{MoO}\left(\mathrm{O}_{2}\right)_{2}\left(\mathrm{C}_{2} \mathrm{O}_{4}\right)\right]$ & Sample treated with $\mathrm{Na}_{2}\left[\mathrm{MoO}\left(\mathrm{O}_{2}\right)_{2}\left(\mathrm{C}_{6} \mathrm{H}_{6} \mathrm{O}_{7}\right)\right]$ \\
\hline $\bar{\Delta} m_{\mathrm{III}}(\%)$ & $29.03 \pm 0.24$ & $19.80 \pm 0.40$ & $21.00 \pm 0.65$ \\
\hline $\bar{\Delta} m_{\mathrm{II}}(\%)$ & $63.43 \pm 0.20$ & $72.80 \pm 0.80$ & $71.20 \pm 0.20$ \\
\hline$R_{1}=\bar{\Delta} m_{\mathrm{III}} / \bar{\Delta} m_{\mathrm{II}}$ & 0.4576 & 0.2719 & 0.2949 \\
\hline
\end{tabular}


It can be concluded that the use of complexes presented in this study has a higher potential in the textile finishing process than the conventional processes in the presence of ultrasound.

\subsubsection{Thermal analysis}

The samples used for the thermal analysis experiments were taken from different sides of the treated fabric in order to eliminate any influence of the material heterogeneity on the registered results. The experiment was repeated 5 times for each sample.

The thermal behaviour of the bleached and unbleached lignocellulosic samples is shown in Fig. 5(a-c).

As it can be observed from the registered curves for all samples, there are three processes of decomposition in the $36-600^{\circ} \mathrm{C}$ temperature range. For each process is recorded of a mass loss.

The first mass loss $\left(\Delta m_{\mathrm{I}}\right)$ is observed between 35 and $120^{\circ} \mathrm{C}$ $\left(T_{\min }^{\mathrm{DTG}}(\mathrm{I})=76 \pm 0.9^{\circ} \mathrm{C}\right)$, and it can be attributed to the humidity present in the fabric, due to the fact that the samples were not conditioned before the experiments.

The second decomposition process that is accompanied by a mass loss $\left(\Delta m_{\mathrm{II}}\right)$ of about $72 \%$ was detected in the temperature range $250-400^{\circ} \mathrm{C}, T_{\min }^{\mathrm{DTG}}(\mathrm{II})=338 \pm 1.5^{\circ} \mathrm{C}$. This mass loss can be due to the thermo-oxidative decomposition of the polysaccharides (cellulose, hemicellulose) and to the lignine oxidation by the complexes.

A last decomposition process $\left(\Delta m_{\mathrm{III}}\right)$ was registered for the temperature range $400-520^{\circ} \mathrm{C}$. In the case of the compound containing oxalate the process is observed at $T_{\min }^{\mathrm{DTG}}(\mathrm{III})=470 \pm 0.5^{\circ} \mathrm{C}$, while for the compound containing citrate this process occurs at $T_{\min }^{\mathrm{DTG}}(\mathrm{III})=473 \pm 0.7^{\circ} \mathrm{C}$. This last process is due to the remaining non-oxidized lignin present in the textile material.

The mean values of the weight loss recorded in the second and third stages as well as the value $R_{1}=\bar{\Delta} m_{\mathrm{III}} / \bar{\Delta} m_{\mathrm{II}}$ are presented in Table 2. $R_{1}$ is an indicator of the change in the amount of lignin present in the ligno-cellulosic materials that are treated with bleaching complexes (Budrugeac \& Emandi, 2010).

The results from Table 2 show that the weight loss for the third process of the TG curve is higher for the fabric treated with the compound with oxalate in its structure. These results mean that the complex containing the oxalate ligand has a higher oxidation capacity than the complex containing the citrate ligand.

These results are in good agreement with the findings from cyclic voltammetry experiments. The value $R=\left(R_{\text {oxalate }} / R_{\text {citrate }}\right) \times$ 100 calculated from Table 2 is the same as the value calculated taking into account the whiteness index of the bleached samples $R^{\prime}=\left(W_{\text {oxalate }} / W_{\text {citrate }}\right) \times 100$. In both cases, the obtained value is $9.22 \%$.

\subsubsection{FT-IR analysis (ATR)}

The sampling was carried out in the similar way as for the thermal analysis experiments. The absorbance was measured at $1515 \mathrm{~cm}^{-1}$ for all samples. The ability of the compounds to oxidize lignin was interpreted based on the peaks height corresponding to the lignin from each treated sample (spectra not shown). It was observed that the peak height for the fabric bleached with $\mathrm{Na}_{2}\left[\mathrm{MoO}\left(\mathrm{O}_{2}\right)_{2}\left(\mathrm{C}_{2} \mathrm{O}_{4}\right)\right]$ is more than two times smaller than corresponding signal for the fabric bleached with $\mathrm{Na}_{2}\left[\mathrm{MoO}\left(\mathrm{O}_{2}\right)_{2}\left(\mathrm{C}_{6} \mathrm{H}_{6} \mathrm{O}_{7}\right)\right]$. It can be concluded that $\mathrm{Na}_{2}\left[\mathrm{MoO}\left(\mathrm{O}_{2}\right)_{2}\left(\mathrm{C}_{2} \mathrm{O}_{4}\right)\right]$ removes more lignin from the treated sample than $\mathrm{Na}_{2}\left[\mathrm{MoO}\left(\mathrm{O}_{2}\right)_{2}\left(\mathrm{C}_{6} \mathrm{H}_{6} \mathrm{O}_{7}\right)\right]$.

\section{Conclusions}

The results obtained from the electrochemical characterization of these two oxo-diperoxo molybdates are in good agreement with those obtained for the analysis of the ligno-cellulosic textile materials that was analyzed by means of whiteness index, thermal analysis and FTIR analysis (ATR). Moreover, all used techniques show that the natrium oxalate-oxo-diperoxo molybdate is oxidizing a higher amount of lignin present in the ligno-cellulosic material which makes it more desirable for textile industrial applications.

The synthesized natrium oxo-diperoxo-molybdates (VI) showed their practical applicability in the textile industry, in the bleaching of the ligno-cellulosic fibres. The results obtained from the analysis of the bleached fabrics are demonstrating that these complexes can be successfully used for the finishing of the textile materials, especially of those with an equal amount of linen and cotton.

\section{Acknowledgements}

This research work was supported by "Bast plants - Renewable Strategic Resources for European Economy". - "BASTEURES" project, No. 210/2010 POS-CCE - supported by Structural Funds Investment in Your Future.

\section{References}

Abdel-Halim, E. S. (2012a). An effective redox system for bleaching cotton cellulose Carbohydrate Polymers, 90(1), 316-321.

Abdel-Halim, E. S. (2012b). Simple and economic bleaching process for cotton fabric Carbohydrate Polymers, 88(4), 1233-1238.

Abdel-Halim, E. S., \& Al-Deyab, S. S. (2011). Low temperature bleaching of cotton cellulose using peracetic acid. Carbohydrate Polymers, 86(2), 988-994.

Abdel-Halim, E. S., \& Al-Deyab, S. S. (2012). Corrigendum to "Low temperature bleaching of cotton cellulose using peracetic acid" [Carbohydr. Polym. $86(2)$ (2011) 988-994]. Carbohydrate Polymers, 87(3), 2365.

Basto, C., Tzanov, T., \& Cavaco-Paulo, A. (2007). Combined ultrasound-laccase assisted bleaching of cotton. Ultrasonics Sonochemistry, 14, 350-354.

Bayot, D., Tinant, B., \& Devillers, M. (2004). Spectroscopic and structural characterizations of ammonium peroxo-carboxylato molybdate(VI) complexes. Inorganica Chimica Acta, 357, 809-816.

Bodescu, A. M., Sîrghie, C., \& Chambrée, D. R. (2011). TG/DTG to monitor the lignin content from flax fibers treated with peroxo complexes of molybdenum (VI). In 1 st Central and Eastern European Conference on Thermal Analysis and Calorimetry.

Bodescu, A. M., Vlase, T., Sîrghie, C., \& Doca, N. (2012). Kinetics of thermal decomposition of natrium oxalato-oxo-diperoxo molibdate. Journal of Thermal Analysis and Calorimetry, 110(3), 1243-1247.

Budrugeac, P., \& Emandi, A. (2010). The use of thermal analysis methods for conservation state determination of historical and/or cultural objects manufactured from lime tree wood. Journal of Thermal Analysis and Calorimetry, 101, 881886.

Dence, C. W., \& Reeve, D. W. (1996). Pulp bleaching. Principles and practice. Atlanta USA: Tappi Press.

Dengel, A. C., Griffith, W.P., Powell, R. D., \& Skapski, A.C.(1987). Studies on transitionmetal peroxo complexes. Part 7. Molybdenum(VI) and tungsten(VI) carboxylato peroxo complexes, and the X-ray crystal structure of $\mathrm{K}_{2}\left[\mathrm{MoO}\left(\mathrm{O}_{2}\right) 2\right.$ (glyc) $] \cdot 2 \mathrm{H}_{2} \mathrm{O}$. Journal of the Chemical Society, Dalton Transactions, 5, 991-995.

El Shafie, A., Fouda, M. M. G., \& Hashem, M. (2009). One-step process for bioscouring and peracetic acid bleaching of cotton fabric. Carbohydrate Polymers 78(2), 302-308.

Evtuguin, D. V., Daniel, A. I. D., Silvestre, A. J. D., Amado, F. M. L., \& Pascoal Neto, C. (2000). Journal of Molecular Catalysis A, 154, 217.

Hiseh, Y., Thompson, J., \& Miller, A. (1996). Water wetting and retention properties of cotton assemblies as affected by alkaline and bleaching treatments. Textile Research Journal, 66, 456-464.

Kubelka, P., \& Munk, F. (1931). Ein Beitrag zur Optik der Farbanstriche. Zeitschrift für technische Physik, 11a, 593-601.

Mistik, S. I., \& Yükseloğlu, S. M. (2005). Hydrogen peroxide bleaching of cotton in utrasonic energy. Ultrasonics, 43, 811-814.

Moholkar, V. S., \& Warmoeskerken, M. M. C. G. (2004). Investigation in mass transfer enhancement in textiles with ultrasound. Chemical Engineering Science, 59, 299-311.

Sîrghie, C., Botar, A., Bodescu, A., \& Dochia, M. 2012. Process for bleaching using peroxo-polyoxometalates for textile (yarns, fabrics and knitted fabrics) made from mixtures of cellulosic fibers such as: flax-cotton, hemp-cotton. European Patent Office, Application No EP 13464006/02.04.2013.

Vigo, T. L. (1994). Textile processing and properties: Preparation, dyeing, finishing and performance. Amsterdam [Netherlands]; New York: Elsevier Science BV.

Weinstock, I. A., Atalla, R. H., Reiner, R. S., Moen, M. A., Hammel, K. E., Houtman, C. J., et al. (1997). Journal of Molecular Catalysis A, 116, 59 . 